Available online at: http://ejournal-balitbang.kkp.go.id/index.php/ifrj
e-mail:ifrj.puslitbangkan@ gmail.com
INDONESIANFISHERIES RESEARCHJOURNAL
Volume 23 Nomor 1 June 2017
p-ISSN: 0853-8980
e-ISSN: 2502-6569
Accreditation Number: 704/AU3/P2MI-LIPI/10/2015

\title{
ANALYSIS 16S RDNA OF THE TURTLES IN FORECLOSURE CAGES AT PADEI
} LAUT, CENTRAL SULAWESI, INDONESIA

\author{
Adriani Sri Nastiti ${ }^{\star 1}$, Masayu Rahmia Anwar Putri ${ }^{1}$, Joni Haryadi ${ }^{1}$, Arif Wibowo ${ }^{2}$ and Ngurah N Wiadnyana ${ }^{3}$ \\ ${ }^{1}$ Research Institute for Fish Resource Enhancement, Jl. Jatiluhur, Purwakarta, Jawa Barat-Indonesia \\ ${ }^{2}$ Research Institute for Inland Fisheries, Jl. Gubernur H, Bastari, Jakabaring, Sumatera Selatan-Indonesia \\ ${ }^{3}$ Research Center of Fisheries, JI. Pasir Putih II, Ancol Timur Jakarta Utara-Indonesia \\ Received; June 20-2017 Received in revised from September 08-2017; Accepted September 12-2017
}

\begin{abstract}
Marine turtle is one of the protected aquatic animals as listed in CITES Appendix and IUCN red list. However, illegal fishing of marine turtle is still occurred Padei Laut Village, in Morowali Regency, Central Sulawesi Province, Indonesia. The research aims to study the population of marine turtle based on the carapace length and the genetic relationships. Data of carapace length was-measured in-situ and genetic analysis was used mitochondrial DNA. The results showed that the carapace (ten samples which was green turtles/Chelonia mydas) was ranges between $42-102 \mathrm{~cm} ; 91 \%$ of samples was immature and $9 \%$ was mature. Moreover, it also revealed that those turtles resembled by $99.98 \%$ of genetic similarity.
\end{abstract}

\begin{abstract}
Keywords: Turtle; carapace; genetic; Sulawesi; Indonesia INTRODUCTION

There is six of seven species of turtles that inhabited in Indonesian waters, namely green turtle (Chelonia mydas), hawksbill (Eretmochelys imbricate), olive ridley turtles (Lepidochelys olivaceae) and leatherbacks (Dermocelys coriaceae). A loggerhead (Caretta caretta) known nesting in Indonesia. While, flat turtle (Natatopterus sp) nested only in Australia, but this species has been observed to foraging in waters of Indonesia (Shanker \& Pilcher, 2003).
\end{abstract}

Sea turtles are protected faunas from extinction under protection status by the State with the category of Appendix I of CITES and IUCN red list, so that all forms of utilization of the turtle should be forbidden. Legal sanctions have been imposed to the perpetrators of turtle utilization activities (poachers, collectors, traders). However, the legal sanction seems ineffective to eliminate the sea turtle poaching, as happened in the Village of Padei Laut.

Nowadays, the population of green turtles in Indonesian water tends to be declined due to the illegal poaching on both eggs and meat for commercial purposes. The increasing disturbance by visitors during nesting period and habitat loss due to abrasion resulting the degradation of turtle nesting habitat
(Nastiti \& Wiadnyana, 2013). Noises generated from water traffic by fisherman, and even fishing gears used with nets opening $35-40 \mathrm{~cm}$ allowing to catch turtles (Aureggi \& DeLucia, 2013).

A Green turtle (Chelonia mydas) is the most common species of sea turtles and live in the tropical ocean. Therefore, the genetic analysis needed to determine the kinship of the population. The green turtle can be recognized from the shape of a small head and a blunt beak. Name of the green turtle is not because scales are green, but the colour of fat located under the green scales. The body colour could be grey, blackish or brownish, and heavy the maximum weight reaching $400 \mathrm{~kg}$ (Nuitja, 1992). Morphological features of green turtle exposed by Hirt (1971) and Bustard (1972), showed the presence of a pair of prefrontal or scales on the head. The turtles have scales shield the back (dorsal shield) which does not impose each other, four pairs of side scales along the surface from the head to the tail (costal scute), wherein the first side scales pair does not touch a nuchal. At the edge of the carapace there are 12 pairs of marginal scute, front legs as paddles shaped flat, there is a toe nail on the large front (Cape et al., 2001). Even turtles have properties "orientation homing" instinct means that the turtles are able to return to their origin place where they were born (Hirth in Nuintja, 1992). 
One effort to reduce the declining of green turtle population is to provide guidance for the public to conserve the green turtle population, as in the Pangumbahan beach, Sukabumi (Wiadnyana \& Nastiti, 2013; Nastiti \& Wiadnyana, 2015). According to Akira et al. (2012), turtles can migrate hundreds and even thousands of kilometres of habitat to find the nesting habitat. During their migration turtles are often susceptible to the poachers as happened in Padei Laut Village, Central Sulawesi, where many turtles have been caught for commercial purpose. This research aims to determine the carapace length and kinship turtle populations from the foreclosures in Padei Laut village. The information of kinship is important to understand the population status.

\section{MATERIALS AND METHODS Sample Preparation}

The observation conducted in Padei Laut Village, Menui District, Morowali Regency, Central Sulawesi that transferred to the cages in Malta Village, South East Sulawesi Province at position $3^{\circ} 58$ ' 2.888 "S $122^{\circ} 36^{\prime} 58.67^{\prime \prime} \mathrm{E}$ (Figure 1). Data and information were collected during period 18 to 20 April 2016.
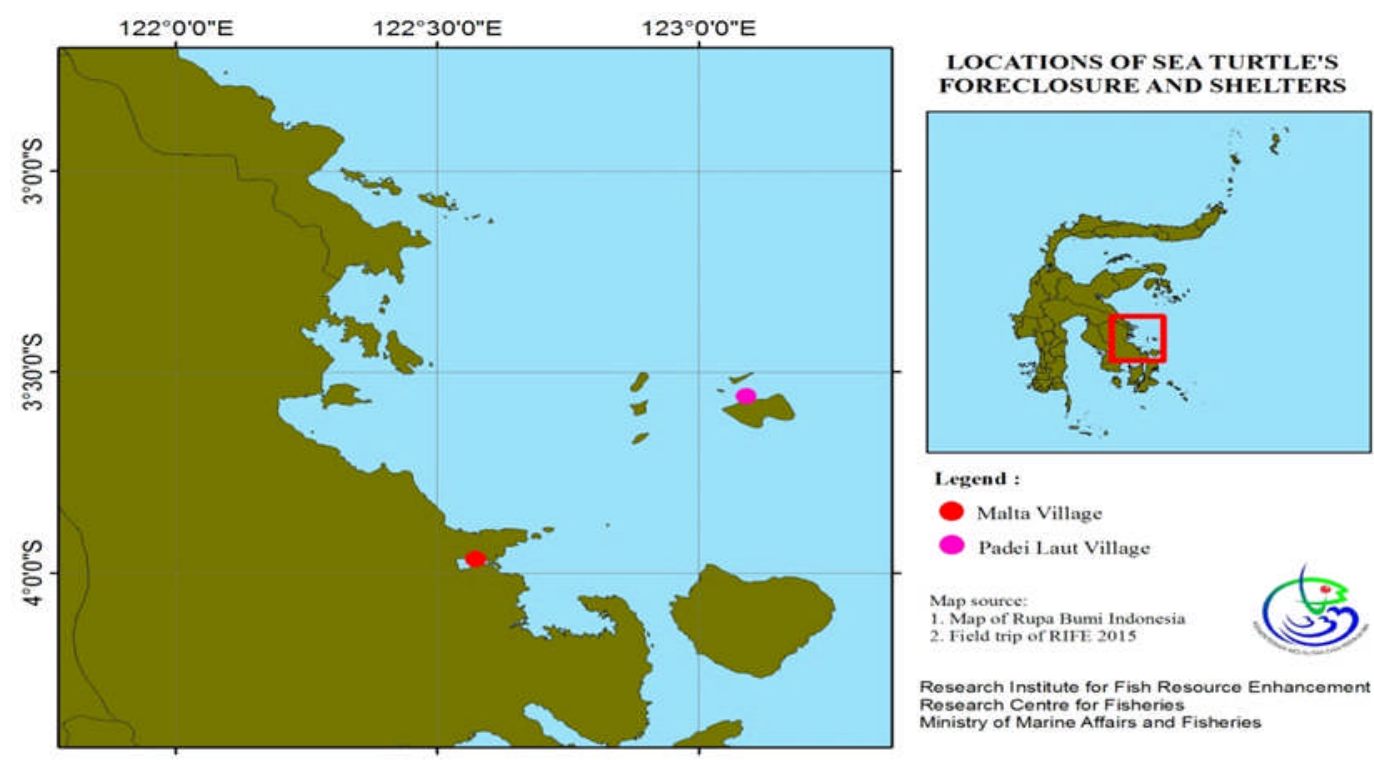

Figure 1. Location of foreclosure and shelters green turtle: Padei Laut Village, Menui Island District, Morowali Regency and OFloating net cage to accommodate the green turtle (Malta Village).

The carapace length of 68 turtles was measured for morphometric data. For genetic analysis, 10 samples were collected randomly (Table 1). Muscle $\left(1 \times 1 \mathrm{~cm}^{2}\right)$ sized was stored in tube contain in absolute alcohol. The DNA preparation was conducted in the Research Institute for Inland Fisheries Indonesia. The genetic data from Gen Bank was sequenced in Macrogen, Inc., South Korea. Genetic analysis is done based primer 16S rDNA gene.

Table 1. The samples of genetic study showing code, and length

\begin{tabular}{lcc}
\hline No. & Tagging Code & Carapace Length $(\mathbf{c m})$ \\
\hline 1 & $9 / \mathrm{KKP} / \mathrm{IV} / 16$ & 56 \\
2 & $4 / \mathrm{KKP} / \mathrm{IV} / 16$ & 44 \\
3 & $1 / \mathrm{KKP} / \mathrm{IV} / 16$ & 43 \\
4 & $11 / \mathrm{KKP} / \mathrm{IV} / 16$ & 50 \\
5 & $19 / \mathrm{KKP} / \mathrm{IV} / 16$ & 44 \\
6 & $2 / \mathrm{KKP} / \mathrm{IV} / 16$ & 43 \\
7 & $3 / \mathrm{KKP} / \mathrm{IV} / 16$ & 45 \\
8 & $6 / \mathrm{KKP} / \mathrm{IV} / 16$ & 42 \\
9 & $13 / \mathrm{KKP} / \mathrm{IV} / 16$ & 66 \\
10 & $18 / \mathrm{KKP} / \mathrm{IV} / 16$ & 49 \\
\hline \hline
\end{tabular}




\section{- Extraction and Isolation of mtDNA}

Genomic DNA isolation was performed using DNA mini kit for blood (Geneaid) modified. The muscle cells of samples stored in $70 \%$ alcohol were washed with distilled water twice and then suspended in STE buffer ( $1 \mathrm{M} \mathrm{NaCl}, 10 \mathrm{mMTris}-\mathrm{HCl}, 0.1 \mathrm{~mm}$ EDTA, $\mathrm{pH}$ 8) to a volume of $350 i$ il. The muscle cells were analyzed by SDS $1 \%$ and proteinase $\mathrm{K} 0.125 \mathrm{mg} / \mathrm{ml}\left(25 \mathrm{uL}\right.$ ) at $55^{\circ} \mathrm{C}$ for 12 hours. The DNA extraction method followed the instructions Genomic DNA mini kit for fresh blood (Geneaid).

\section{- Amplification and Visualization Fragments of mtDNA}

Amplification of 16S rRNA gene fragment portion used a universal primer Palumbi (1991) 16Sar - 5'1 CGCCTGTTTATCAAAAACAT and 16Sbr-3'1 CCGGTCTGAACTCAGATCACGT. The composition of the PCR reaction was carried out with a final volume of $50 \mathrm{~mL}$ of sample DNA consists of $5 \mathrm{~mL}, 16 \mathrm{~mL}$ sterile DW, each primer $2 \mathrm{~mL}$ and $25 \mathrm{~mL}$ Taq ready mix. PCR reactions were performed using a machine thermocycler applied Biosystems with the following conditions: pre-denaturation $95^{\circ} \mathrm{C}$ for 10 minutes, the second phase was consisting of 35 cycles, each of which includes a stage of denaturation $94^{\circ} \mathrm{C}$ for one minute, annealing on temperature of $48^{\circ} \mathrm{C}$ for one minute, extension at $72^{\circ} \mathrm{C}$ for 1.5 minutes and the last phase is the elongation of the final extension at $72^{\circ} \mathrm{C}$ for 7 $\mathrm{min}$. The PCR products were tested using PAGE $6 \%$ in $1 \times$ TBE buffer ( $10 \mathrm{Mm}$ Tris- $\mathrm{HCl}, 1 \mathrm{M}$ boric acid, and 0.1 Mm EDTA) were run at $200 \mathrm{Mv}$ conditions for 30 minutes. Furthermore, sensitive DNA stained by silver.

\section{- Tracking PCR Products}

PCR products on polyacrylamide gels in size are in accordance with the primary design purified by the method of spin-column DNA purification kit. PCR products were purified and used in PCR for sequencing using the same primer pairs with initial amplification.

\section{Data Analysis}

Results tracing nucleotide were edited manually by the chromatogram. Nucleotide sequences that have been edited using the Clustal $W$ were embedded in 4.0 MEGA (Molecular Evolutionary Genetics Analysis) (Tamura et al., 2007).

\section{Analysis of Phylogeny (kinship)}

Analysis of phylogeny Neighbour Joining $(\mathrm{NJ})$ was done using the MEGA 4.0 (Tamura et al., 2007), based on the model of nucleotide substitution Kimura-2parameter with bootstrap 100 times.

\section{. The Genetic Distance}

Genetic distance was analyzed based on the formula proposed by Nei (1987), and performed using MEGA 4.0 (Tamura et al., 2007):

$$
I=\frac{J a b}{\sqrt{J a i J b i}}
$$

were;

$\mathrm{i}=$ Haplotype to $\mathrm{i}$

ai = Haplotype frequencies to-i from A population.

bi = Haplotype frequencies to- $\mathrm{i}$ from $\mathrm{B}$ population.

Jaibi $=$ Multiplication frequency haplotype to- $\mathrm{i}$ of the population $A$ and frequencies haplotype to- $i$ in $B$ population $\overline{j a} \overline{j b}$ is the average $\mathrm{Ja}$, $\mathrm{jb}$ for all haplotype

\section{RESULTS AND DISCUSSION \\ Result}

The carapace lengths of turtles are raging between 42- $102 \mathrm{~cm}$. Based on the size and characteristics, turtles are divided into four categories such as: young hatchling, hatchlings, young and adult sea turtles. In this observation, most turtles are as young hatchling and hatchling ( $91 \%$ of 68 turtles) with sizes of $40-80$ $\mathrm{cm}$, while adult sea turtle were only 6 animals $(9 \%)$. In those ranges of size, it seems to be difficult to identify the species correctly, except the adults were recognized as green turtles.

Amplification of the $16 \mathrm{~S}$ rDNAgene produced 600 bp fragments at position 2,954-3,547 that all the observed sample were green turtle (Chelonia mydas) (Figure 2).

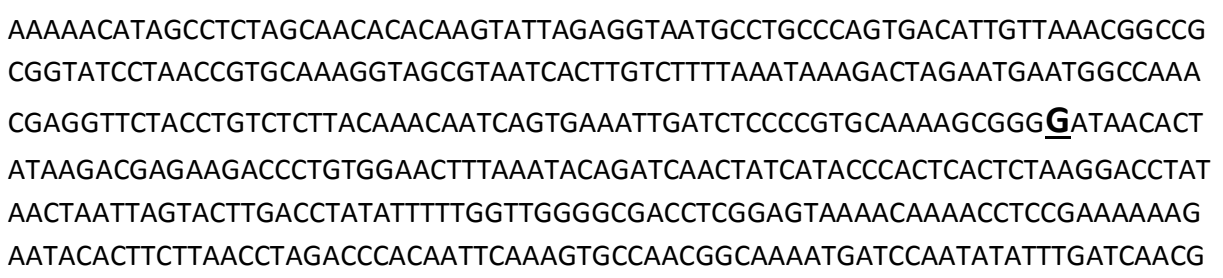

Figure 2. $16 \mathrm{~S}$ rDNA Partial sequence mtDNA of $C$. mydas (528 bp). SNP (Single Nucleotide Polymorphism) showed by bold and underlined text. 


\section{Discussion}

After comprehensive analysis, 70 examined green turtles from the Padei Laut Village, were confirmed as a child or young (young hatchling and hatchling) green followed the criterias given by Nuitja, (1992) and Nastiti et al. (2008). In nature, young hatchling and hatchling turtle, live in the sea water area that abundance with Sargassum seaweed as their main feed. According to Bjorndal (1997), beside seaweed, the turtle also consumes other organisms such as fish jelly and sponge. In the Gulf of California, green turtle dives in 1.3 to $7 \mathrm{~m}$ water depth (Seminoff et al., 2006). Swimmer et al. (2007), mentioned that the survival of turtle much influenced by physiological and behavioural aspect. Allison et al. (2009) stated that the injury suffered by the turtle will affect the ability of the turtle to migrate, escape from predators and reproduction ability. The genetic distance or intraspecific variation from samples (Figure 3 ).

\begin{tabular}{|c|c|c|c|c|c|c|c|c|c|c|c|c|c|c|}
\hline & 1 & 2 & 4 & 5 & 6 & 7 & 8 & $\theta$ & 10 & 11 & 12 & 13 & 14 & 15 \\
\hline 1.JX454976.1/Chelonia_mydas & & & & & & & & & & & & & & \\
\hline 2 FJ039956.1/Natator_depressa & 0.031 & & & & & & & & & & & & & \\
\hline 3 KP250531.1/Caretta_caretta & 0.059 & 0,057 & & & & & & & & & & & & \\
\hline 4 JX454982.1/Lepidochelys_kempii & 0.063 & $0,065 \quad 0.023$ & & & & & & & & & & & & \\
\hline 5 DQ486893.1|Lepidochelys_olivacea & 0.067 & $0,0700,031$ & 0.012 & & & & & & & & & & & \\
\hline 6 FJ039914.1LDermochelys_ooriacea & 0,055 & 0.0650 .061 & 0.061 & 0.065 & & & & & & & & & & \\
\hline 71 jt & 0,000 & 0.0310 .059 & 0.063 & 0,067 & 0,055 & & & & & & & & & \\
\hline 82 jt & 0.002 & $0,0330,001$ & 0.061 & 0,065 & 0.053 & 0.002 & & & & & & & & \\
\hline 93 jt & 0.002 & $0,0330,061$ & 0.081 & 0,065 & 0.053 & 0.002 & 0.000 & & & & & & & \\
\hline $104 \mathrm{jt}$ & 0,000 & 0.0310 .059 & 0.063 & 0.067 & 0.055 & 0.000 & 0.002 & 20.002 & & & & & & \\
\hline $115 \mathrm{jt}$ & 0,002 & $0,0330.061$ & 0,061 & 0.065 & 0,053 & 0,002 & 0.000 & 0,000 & 0,002 & & & & & \\
\hline 12 6 jt & 0.000 & 0.0310 .059 & 0.003 & 0.067 & 0.055 & 0.000 & 0.002 & 20,002 & 20.000 & 0.002 & & & & \\
\hline $137 \mathrm{jt}$ & 0.002 & $0,0330,081$ & 0,061 & 0.085 & 0.053 & 0.002 & 0,000 & 0.000 & 0.002 & 0.000 & 0.002 & & & \\
\hline 148 jt & 0,000 & 0.0310 .059 & 0.003 & 0.067 & 0.055 & 0.000 & 0,002 & 20.002 & 20.000 & 0.002 & 0.000 & 0.002 & & \\
\hline 159 jt & 0.002 & 0.0330 .061 & 0,061 & 0.065 & 0.053 & 0,002 & 0.000 & 0,000 & 0,002 & 0.000 & 0,002 & 0.000 & 0,002 & \\
\hline $1610 \_j t$ & 0,002 & 0.0330 .061 & 0.001 & 0,065 & 0,053 & 0,002 & 0.000 & 0,000 & 0.002 & 0.000 & 0,002 & 0.000 & 0.002 & 0.000 \\
\hline
\end{tabular}

Figure 3. The genetic distance or intra-specific variation from samples and reference species from Gen bank.

Results of phylogram based on 16S r-DNA gene nucleotide inform that the analysed samples are Chelonia mydas with the level of $99.98 \%$ genetic similarity (Figure 4). The genetic variation was existing in the transition, the pattern $\mathrm{A}$ (adenine at position $2,174 \mathrm{bp})$ found in four samples together with the referent from Gen Bank. The pattern $\mathrm{G}$ (guanine at position 2,174 pb) was found in another 6 samples.

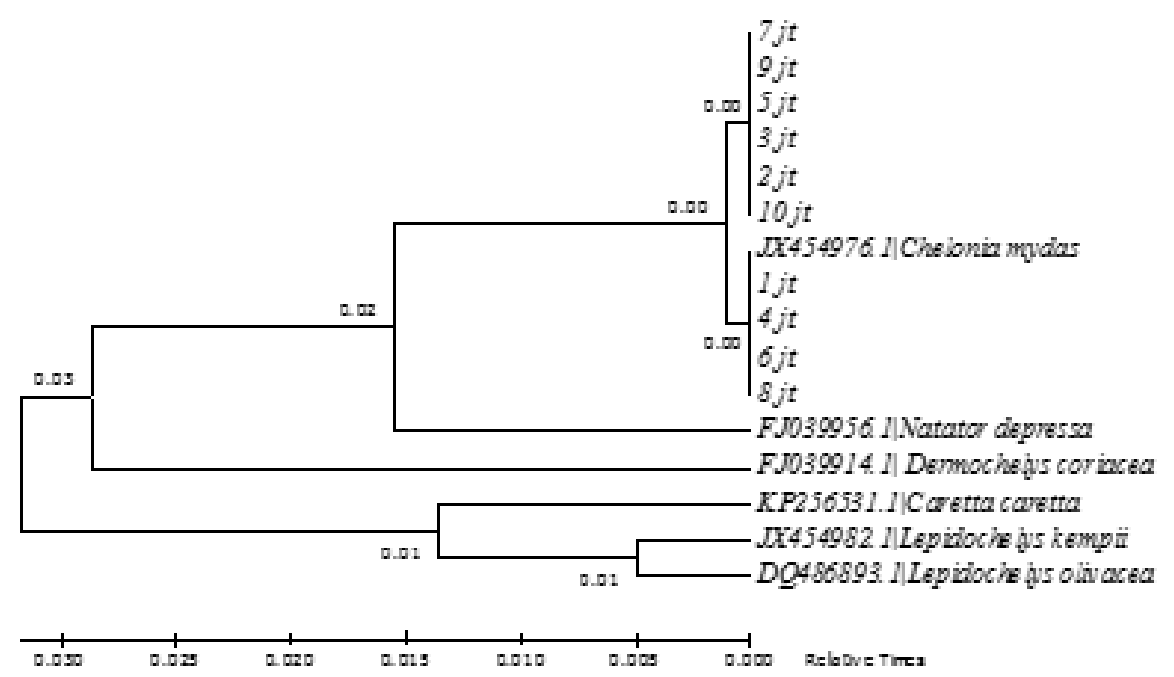

Figure 4. Neighbour Joining parameter phylogram from fish collection and the reference of species.

According to Nastiti et al. (2008) genetic analysis carried out on green turtles on the south coast of West Java, Indonesia (Citireum, Pangumbahan, Cipatujah and Legok Java) have a common origin in the history of evolution, due the long distance of turtle migration (high mobility) (Spotila, 2004) (Figure 5). It is assumed that the turtle population in a region derived from the same parent stock. 


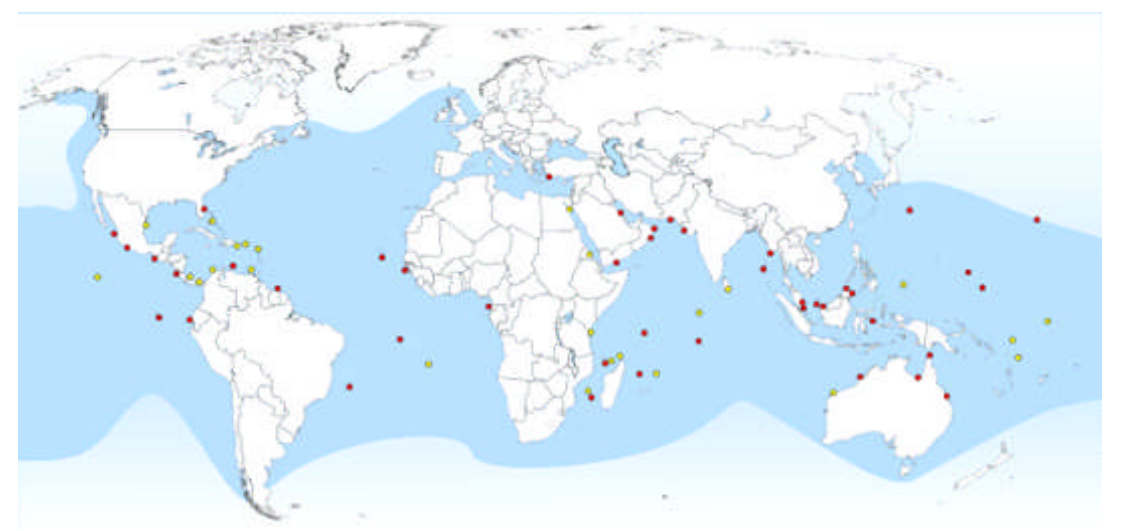

Figure 5. World distribution of green turtle (C. mydas) (Spotila, 2004).

Fuentes et al. (2013) stated that the fitness of turtle populations will support diversity, and geographical distribution in the world. Even though, wide distribution of green exist in the world, they still need suitable region for certain phase of their life such as to breed and grow out at early life history, such as Indonesian waters.

Previous study on the population of the green turtle from 7 different nest site in Indonesia (Sukamade, Pangumbahan, Sangalaki Island, Derawan, Piai Island, Enu Island, and Paloh) showed they were different each other's enabling to be used as population stock (Dermawan et al., 2009). Among the population observed, only the population of the turtles from Paloh beach has closely relationship to the turtles from Sarawak (Moritz et al., 2002).

The study of post-nesting migration green turtles in Indonesia have been conducted in several nesting sites, such as Raja Ampat in Papua (Gearheart, 2005), Misol in Papua (Adnyana \& Jayaratha, 2009), Berau in East Kalimantan (Adnyana et al., 2008) and Sukamade in East Java (Dermawan et al., 2009). The results showed that only a small percentage of turtles in the feeding area comes from the near spawning areas. Most of the turtles migrate to the new areas for grow out within thousands of kilometres distance from the spawning sites. This phenomenon showed a consistency of pathway and destination. In supporting of the management of sea turtles along the coast of Sulawesi, Indonesia, it would be urgent to study bioecology, socio-economic and institutional responsibility as the basis for green turtle conservation. That information could be used to setup management measures of nesting habitat as well as to develop the climate change mitigation for turtle.

\section{CONCLUSION}

The current investigation confirmed that the sea turtles observed are the green turtles (Chelonia mydas) based on 16S rDNA analysis. Moreover, it revealed that the green turtle have $99.98 \%$ genetic similarity.

\section{ACKNOWLEDGEMENTS}

This study was a part of the Crash Program to Research Institute for Fisheries Enhancement and Conservation, Indonesia in 2016. The author thank to head of Research Institute for Fish Resource Enhancement (RIFRE)-Agency for Marine Affairs and Fisheries Research and Human Resources (AMAFRHR) for suporting this work.

\section{REFERENCES}

Adnyana, I. B.W., Pet Soede. L., Gearheart. G. \& Halim, M. (2008). Status of Green Turtle (Chelonia mydas) Nesting and Foraging Populations of Berau, East Kalimantan, Indonesia, Including Results from Tagging and Telemetry. Report to WWF Indonesia Turtle Program. Indiana Ocean Turtle Newsletter7: 2-11.

Akira,R., Wandia. I.N. \& Anyana, I.B.W. (2012). Komposisi Genetik Penyu Hijau (Chelonia mydas) Hasil Tangkapan Liar dari Nusa Tenggara Barat (Bima dan Teluk Cempi). Indonesia Medicus Veterinus, 2012 1(1), 22-36.

Allison, D., Griffin, E., Miller, K.L. \& Rider, S. (2009). U.S. Sea Turtles: A Comprehensive Overview of Six Troubled Species. OCEANA.org/seaturtle. 36p.

Aureggi, M. \& De Lucia, A. (2013). Conservation Actionln Small Sea Turtle Feeding Area AtPhra Thong, Thailand. Proceedings the design symposium on conservation of ecosystem (SEASTAR 2000). Kyoto University. By Arai. N. Edited. March, 1-7. 
Bjorndal, K.A. (1997). Foraging ecology and nutrition of sea turtles. Pages 199-231 in P. L. Lutz and J. A. Musick (eds.), the biology of sea turtles. CRC Press, Boca Raton, Florida.

Bustard, R.H. (1972). Natural History and Conservation, Taplinger Publishing Company, New York.

Dermawan, A., Nuitja, N.S., Soedharma, D.,Halim, M.H., Kusrini, M.D., Lubis, S.B., Alhanif, R., Khazali, M., Murdiah, M., Wahjuhardini, P.L., Setiabudiningsih. \& Mashar, A. (2009). Pedoman Teknis Pengelolaan Konservasi Penyu. Direktorat Konservasi dan Taman Nasional Laut, Direktorat Jenderal Kelautan, Pesisir dan Pulau-Pulau Kecil, Departemen Kelautan dan Perikanan RI. 62p.

Fuentes, M. M. P. B., Pike, D.A., DiMatteo, A. \& Wallace, B.P. (2013). Resilience of Regional Marine Turtle Management Units to Climate Change. Global Change Biology (2013) 19, 1399-1406.

Gearheart, G. (2005). Raja Ampat sea-turtle satellite tracking project: an endangerd green turtle nesting colony in P. Sayang and P. Piai, the elusive hawksbill of Misoo land first tracking results. Unpublished report to Conservation InternationalIndonesia.

Ivanova N.V., Zemlak. T.S., Hanner.R.H. \& Hebert, P.D.N. (2007).Universal primer cocktails for fish DNA barcoding. Molecular Ecology Notes 7, 544548

Moritz, C., Broderick, D., Dethmers, K. Fitzsimmons, N.N. \& Limpus, C.J. (2002). Population Genetics of South East Asian and Western Pacific Green Turtles, Cheloniamydas. Final Report to UNEP / CMS.

Nastiti, A.S. \& Wiadnyana, N.N. (2013). Management Of Green Turtle Eggs (Chelonia mydas) As One of Supporting Aspect For Its Sustainability In Pangumbahan Beach, Sukabumi Regency, West Java Province, Indonesia. Proceedings the design symposium on conservation of ecosystem (SEASTAR 2000). Kyoto University. By Arai. N. Edited. March, 21-28.

Nastiti, U.S., Satria. F. \& Wiadnyana, N.N. (2015). An Update on Conservation Management of The Green Turtle (Chelonia mydas) on Pangumbahan Beach, Sukabumi Indonesia. Proceedings the design symposium on conservation of ecosystem. Kyoto University. By Arai. N. Edited Volume 3 (The 14th SEASTAR 2000 Workshop). March, 11-18.
Nastiti, A.S., Wiadnyana, N.N., Nurfiarini, A., Oktaviani, D., Rahmadi, P. \& Fitriyanto, A. (2008). Evaluation of Turtle Conservation in the Southern Coast Of Java (West Java And Banten). Technical Report. Institute of Fish Stock Research. Capture Fisheries Research Center. BRKP -DKP: 89 pp.

Nei, M. (1987). Genetic distance and molecular phylogeny. In: Population Genetics and Fishery Management (N. Ryman and F. Utter, eds.), University of Washington Press, Seattle, WA, pp. 193-223.

Nuitja. N.S. (1992). Biology and Ecology Conservation of Sea Turtles. IPB. Bogor.

Palumbi, S.R., Martin, A., Romano, S., McMillan, W, O., Stice, L. \& Grabowski, G. (1991). The Simple Fool's Guide to PCR, Version 2. University of Hawaii Zoology Department, Honolulu.

Shanker, K. \& Pilcher, N.J. (2003). Marine turtles in South and South East Asia: hopeless cause or cause for hope? Mar. Turtle Newsl, 100, 43-51.

Seminoff, J.A., Jones, T.T. \& Marshall, G.J. (2006). Underwater Behavior Of Green Turtles Monitored With Video-Time-Depth Recorders: What's Missing from Dive Profiles? Mar. Ecol. Prog. Ser. 322: $269-280$.

Spotila, J. (2004). Sea Turtles: A Complete Guide to Their Biology, Behavior, and Conservation. Baltimore, MD: Johns Hopkins University Press.

Swimmer, Y., Wang, J., Southwood, S., Eckert, S., Stroud, E., Campora, C.E. \& Judith, L. (2007). Environmental Assessment Sea Turtle By catch Reduction Research Activities at the Pacific Islands Fisheries Science Center. 51p. National Oceanic and Atmospheric Administration.

Tamura. K., Dudley .J., Nei.M. \& Kumar, S. (2007). Molecular biology and evolution. MEGA4: volutionary molecular genetics analysis (MEGA) software version 4.0.

Wiadnyana, N.N. \& Nastiti, A.S. (2013). Sea turtle management progress of Pangumbahan beach, Sukabumi district, West Java-Indonesia. Proceedings the design symposium on conservation of ecosystem (SEASTAR 2000). Kyoto University. By Arai. N. Edited March, 2935. 